\title{
REFLECTIONS ON THE INTEREST IN BUYING SMARTPHONE PRODUCTS AMONG MILLENNIALS: CONSUMER SATISFACTION AS THE MEDIATING EFFECT
}

\author{
Fitria Halim ${ }^{1}$, Hendra Jonathan Sibarani ${ }^{2}$, Brilian Moktar ${ }^{3}$, Maria \\ Sugiat $^{4}$, Acai Sudirman ${ }^{5 *}$ \\ ${ }^{1}$ Doctor in Management Department, Universitas Prima Indonesia \\ 2,3Management Department, Universitas Prima Indonesia \\ ${ }^{4}$ Management Department, Universitas Telkom, Indonesia \\ ${ }^{5}$ Management Department, Sekolah Tinggi Ilmu Ekonomi Sultan Agung, \\ Indonesia
}

\begin{abstract}
The urgency of this study is to determine the role of consumer satisfaction as a mediating variable between product attributes and price on the purchase interest of smartphones among millennials. This study obtains the data using a survey through 240 online questionnaires with a quantitative approach. The PLS-SEM statistics are initiated with the outer model's quality tests and the inferential statistics in the inner model. Based on data analysis on the effect of mediation, it can be seen that consumer satisfaction is not able to mediate the relationship between product attributes and purchase intention. Meanwhile, in the pattern of the relationship between price and purchase intention, it turns out that consumer satisfaction can be a mediating variable.
\end{abstract}

Keywords: Attribute Product; Price; Customer Satisfaction; Purchase Intention; Smartphone

Submitted: 26 March 2021; Revised: 22 March, 5 \& 9 April 2021; Accepted: 20 May 2021

*Corresponding author : acaivenly@stiesultanagung.ac.id

DOI: $10.24252 /$ minds.v8i1.20402

ISSN-E: 2597-6990

ISSN-P: 2442-4951

http://journal.uin-alauddin.ac.id/index.php/minds

Publisher: Program Studi Manajemen Universitas Islam Negeri Alauddin Makassar 


\section{INTRODUCTION}

The use of smartphones is currently growing exponentially, as well as becoming a requirement in daily life. The original use of mobile phones may only be for creating phone calls or transmitting messages relative to the previous period, but nowadays, smartphones have expanded from the area of utility to satisfy social needs (Sudirman, Halim, Pakpahan, et al., 2020). Current technological developments provide space for consumers to choose a variety of smartphone product brands. The combination of brands available in the market has supplied mobile phone brands to create attractive features for customers (Choudhury \& Gulati, 2020). Maintaining the existence of satisfaction from a customer is one of the goals of all business companies. The position of smartphones as a means of communication has now become a fundamental need for society. The existence of a smartphone product is very dependent on brand management managed by the company and industry (Ramaseshan \& Stein, 2014). Manifestation in the form of an emotional bond between customers and the attributes used by the product is part of the effort to carry out the ideal branding process (Ilyas et al., 2020).

Each product can be perceived differently according to the attribute contribution to the level of satisfaction (Ahmad \& Barukab, 2020). Not only is the role of smartphones a means of communication, but now it has become a critical necessity for society (Hoffmann et al., 2020). This condition illustrates the urgency of the product attributes needed to find out which product properties contribute to customer satisfaction (Imtiaz \& Islam, 2020). Lin et al. (2017) also stated that current products are developed following market needs with an orientation to consumer desires so that the creation of quality product attributes is essential. Several studies say that consumer satisfaction is more or less influenced by the characteristics of a product (Biswas et al., 2020) and has implications for a consumer's buying interest (Lee et al., 2017). However, several studies have concluded different things, such as the results of the research presented (Soujanya \& Daniel, 2020), who reported that there was no significant effect of the existence of product attributes on customer satisfaction and the study results (Cho et al., 2020), which says that there is no significant effect of the presence of product attributes on purchase intention.

Price is an essential element in consumer purchases, so it dramatically influences consumer judgment when making purchases (Herrmann et al., 2007). The primary factor behind an individual's happiness is primarily determined by an estimation of the price of a good when a transaction is made (Wantara \& Tambrin, 2019). Price discounts significantly affect high product prices and increase product value (Katt \& Meixner, 2020). The benchmark of customer satisfaction can measure price stability after getting the product by reviewing 
the price first before initiating to buy back the product (Sudirman, Halim, \& Pinem, 2020). Research has proven that price affects consumer satisfaction (Oktarini, 2019); (Zhong \& Moon, 2020) and has a contribution to consumer purchase intentions (Hsu et al., 2017); (Satria, 2017); (Wijaya \& Kinder, 2020). However, the study results (Kurniawati et al., 2019), conveying that the fixing of a price does not have a significant contribution to the level of customer satisfaction, and in other studies, price penetration does not affect purchase intention, according to the research results (Khaleeli et al., 2021).

Reflecting on one's customer satisfaction is a crucial part of any organization that wants to increase its customer commitment and generate better business revenue (Masud et al., 2011). Customers want to find relevant data from different products by equating and carrying out an assessment before purchasing terms (Ali, 2016). The impression of poor scores is due to a lack of consistency with prior standards that can contribute to the amount of satisfaction received (Nugroho et al., 2015). In general, if the perceived value exceeds the cost to buy, the consumer is satisfied and tends to make a repurchase decision (Chi, 2018). Several studies have shown that a consumer's satisfaction has contributed to increased purchase intention (Chen, 2013; Resti, Devi; Soesanto, 2016). On the other hand, a study is being carried out (Putra et al., 2020), discovering various outcomes, notably that consumer loyalty does not substantially impact the urge or motivation to purchase a customer.

The urgency of this study is to answer the gaps in the results of previous studies, which convey different research results about product attributes, prices, and consumer satisfaction with purchase intention. The new thing shown from this research is the use of research samples from the perceptions of millennial generation respondents. There is a lack in the study examining smartphone product attributes and price as determining factors for a person to repeat purchasing activities after obtaining satisfaction. Researchers have the opportunity to conduct further research related to customer buying interest based on the conversation above.

\section{THEORETICAL REVIEW}

\section{Product Attribute}

The attributes attached to the product are essential components that can encourage consumers to make purchases (Suhatman et al., 2020). There are elements in product characteristics that consumers generally desire and need, such as prices, brands, packages, and other product characteristics (Evanita \& Trinanda, 2017). Furthermore, opinions about product attributes were also expressed by (Ann et al., 2018), which says the product's appearance, such as color, size, weight, material composition, after-sales service is part of the tangible product attributes. As for the intangible qualities characterized by everything that cannot be touched and felt, such as reliability, beauty, quality, and price (Hoffmann et al., 2020). Meanwhile, according to (Kang et al., 2014), 
several vital factors drive the success of smartphones, including the reliability of the browser, application features, navigation interface, and fashionable design.

Further research results (Goh et al., 2016) support the two previous studies, with research results that point to the significance of product attributes in influencing consumer satisfaction of smartphone users. The same thing was conveyed by (Martins et al., 2019) with the flow experience theory approach; the results of the study state that product attributes in the form of web design quality have a strong enough influence on purchase interest. Further study results (Toufani et al., 2017) through the approach of the theory of consumption values and the theory of consumer values, results of the study are contrary to the results of previous studies, which state that product attributes (color, design, overall appearance, texture, beauty, and shape) do not affect purchase intention. Therefore, based on some of the results of previous research, this study leads to the development of a hypothesis:

$H_{1}$ : Product attributes affect customer satisfaction

$\mathrm{H}_{3}$ : Product attributes affect purchase intention

Price

Price is the amount of value that customers exchange for a product's utility (Handoko, 2017). Price markers have an advantageous position in how to change objects with special pricing procedures. Price is like a determinant of sales and is often linked to a customer's financial capacity (Lie et al., 2019). Furthermore, price is something that is sacrificed or given up to obtain a product or service. Interpretation of discounted prices is about lower prices and getting the same service as the price ratio that consumers receive when buying products (Bhatti, 2018). Prices for the industry are used as a determinant of marketing creation and are always linked to the financial capacity of customers (Lie et al., 2019). Consumers, from a marketing perspective, often judge products based on price. Therefore, there is a solid reason why smartphones are priced moderately because all smartphone manufacturers claim that their products have good features (Sudirman, Halim, \& Pinem, 2020). Studies conducted by (Rama, 2020), by using the measurement of price reliability, price confidence, price transparency, relative price, price-quality ratio, price fairness, convey that price has a crucial role in influencing consumer satisfaction. Next, research (Pandey et al., 2020) describes the consequence of prices based on variations like the product when buying online product categories impacts customer satisfaction, trust, and loyalty. The same thing was conveyed (Ali Qalati et al., 2019) with research on the impact of prices on customer satisfaction in the telecommunications sector. Sharing prices has a powerful influence on customer satisfaction when purchasing telecommunications products. Studies conducted by (Bringula et al., 2018) with the theory of planned behavior (TPB) 
approach revealed that the price offer was initially considered when buying a smartphone. Likewise, with research (Satriawan \& Setiawan, 2020), the study results found that the perceived price and quality positively and significantly affect purchase intention and purchase decision of Xiaomi smartphones. This finding is not supported by research (Wong, 2019) conducted in Hong Kong, that price is not a significant factor affecting the purchase interest of a Smartphone. Therefore, based on some of the results of previous research, this study leads to the development of a hypothesis:

$\mathrm{H}_{2}$ : Price affects customer satisfaction

$H_{4}$ : Price affects buying interest

\section{Customer Satisfaction}

Satisfaction is an after-purchase evaluation after using a product to evaluate the actual performance of a product related to expectations and expectations before purchasing (Hasan, 2013). The relationship between expectations of using development and implementing reality after using the product is one form of manifestation that appears when the connection is as expected or not as expected (Nugroho et al., 2015). Customer satisfaction is a fundamental goal of a company in carrying out its business activities so that it is expected to bring profit to the company (Hasan, 2013). The relationship between expectations of using a product and the implementation of reality after using the product is one form of manifestation that appears when the connection is as expected or not as expected (Hossain \& Zhou, 2018). According to (Zephan, 2018), Consumer satisfaction can be understood as the difference between customer expectations before consumption and realization after consuming a product or service so that the feeling of satisfaction after using a product is expected to have implications for the company's long-term survival (Sudirman, Sherly, et al., 2020). Studies conducted by (Dash et al., 2021) with the topic of Marketing to Millennials: Marketing 4.0, customer satisfaction, and purchase intention state that consumer satisfaction has a powerful influence on purchase interest. The same thing was conveyed by (Ilyas et al., 2020), with the results of the research discussion explaining that consumer satisfaction has a significant effect on purchase intention. The two previous studies were also supported by the results of the studies presented by (Hsiao et al., 2016), through the approach of the theory of reasoned action (TRA), planned behavior (TPB), and technology acceptance model (TAM), which states that a person's intention to use a product is strongly influenced by the level of satisfaction received. Therefore, based on some of the results of previous research, this study leads to the development of a hypothesis:

\section{$H_{5}$ : Consumer satisfaction affects purchase intention}




\section{Purchase Intention}

Purchase interest can be defined as someone's inclination to use or buy a product obtained by a company where this attention is established after the initial consumption activity that the customer tries to do (Hsu et al., 2012). Furthermore, purchase intention is the desire of a customer to buy because the customer wants that product or service that causes action and perception (Madahi \& Sukati, 2012). The reflection of the desire to buy can be observed at the stage of the customer in sorting out among several brand options, after which he finally makes a purchase that comes from many considerations (Murtingsih et al., 2019). The plan to purchase a product can be reflected as an effort from a mental statement that describes buying interest (Japarianto \& Adelia, 2020). A situation that reflects a person's intention to purchase a product or service from a company or industry can occur because of a strong desire and impulse that arises from the mind (Wilson et al., 2019). It explains that someone's buying interest is influenced by product attribute factors, price, and customer satisfaction. Therefore, based on some of the results of previous research, this study leads to the development of a hypothesis:

\section{$H_{6}$ : Customer satisfaction mediates the relationship between product attributes on purchase intention \\ $H_{7}$ : Customer satisfaction mediates the relationship between price and purchase intention}

\section{METHODOLOGY}

Methods with a quantitative approach to causality are used in this study. For data analysis using the PLS-SEM concept, which consists of two processes (1) the research data is analyzed for its validity and reliability using the Cronbach's alpha test, composite reliability, outer loading, and average variance extracted. Then (2) confirmatory factor analysis to check the fit of the model and model reliability and discuss the hypothesis through the variance-based Structural Equation Model (SEM) (Hair, 2014). The questionnaire distributed online is used as a medium for collecting data in the field. The population in this study were all consumers who use smartphones in Pematangsiantar City. The sampling technique used nonprobability sampling using the purposive sampling method (Ghozali, 2014). From the questionnaires distributed online using social media, 328 respondents obtained data. However, only 240 respondents $(73.17 \%)$ met the criteria to be sampled because they had filled in the data, answered questions completely, and met the characteristics of research respondents. For the construct measurement of the first exogenous variable, the product attribute consists of the item price, quality, brand, fashionableness, prestige, attractiveness, trustworthiness (Chang, 2011; Y. Wang et al., 2018). The second exogenous variable, namely price, consists of item's affordability of 
costs, prices are following product quality, price competitiveness, price compatibility with product advantages (Herrmann et al., 2007; Kotler \& Armstrong, 2008). The mediation variable, namely customer satisfaction, consists of items, feel service quality, professional feel competence, feel the experience with the product, feel contented with the services (Zhou, 2011; Dash et al., 2021). The endogenous variable of buying interest consists of intent to purchase, search information about, always talk about smartphones, the purchase is beneficial, and recommend buying (Cheong \& Morrison, 2008; Kaushal \& Kumar, 2016).

\section{Respondent Description}

Respondents in this study were consumers who used smartphones. Respondents in this study can be categorized into several characteristics, namely: gender, age, employment status, income level, and the brand of smartphone used.

Table 1. Description of Respondents

\begin{tabular}{cccc}
\hline Category & Detail & amount & Percentage \\
\hline \multirow{2}{*}{ Gender } & Men & 104 & $43.4 \%$ \\
& Woman & 136 & $56.7 \%$ \\
Age & $24-27$ & 72 & $30 \%$ \\
& $28-31$ & 106 & $44.2 \%$ \\
& $32-35$ & 44 & $18.3 \%$ \\
Job status & $36-39$ & 18 & $7.5 \%$ \\
& College student & 6 & $2.5 \%$ \\
& Teacher / Lecturer & 27 & $11.25 \%$ \\
Income Within a & Employees & 98 & $40.83 \%$ \\
Month & Government employees & 70 & $29.17 \%$ \\
& Entrepreneur & 39 & $16.25 \%$ \\
& $<1$ million & 6 & $2.5 \%$ \\
& 1 million - 5 million & 125 & $52.09 \%$ \\
Smartphone & million - 10 million & 64 & $26.66 \%$ \\
Brand Used & $>10$ million & 45 & $18.75 \%$ \\
& Samsung & 43 & $17.92 \%$ \\
& iPhone & 47 & $19.58 \%$ \\
& Vivo & 82 & $34.17 \%$ \\
& Oppo & 54 & $22.5 \%$ \\
& Others & 14 & $5.83 \%$ \\
\hline
\end{tabular}

\section{Outer Model Measurement}

In measuring the outer model, the tests carried out are validity and reliability tests. The loading factor and AVE determine convergent validity testing with the condition that the loading factor is above 0.7 and the AVE value 
is 0.5 (Hair, 2014). However, for research still in the development stage, the acquisition of a loading factor value between 0.50 and 0.60 is still acceptable (Ghozali, 2014). Model reliability testing, according to (Hair et al., 2014), seen from the value of Cronbach's alpha and composite reliability (CR), which has a value greater than 0.7 , which is presented using table 2 :

Table 2. Outer Model Measurement

\begin{tabular}{|c|c|c|c|c|}
\hline Construct/item & Loadings & Alpha & $\mathrm{CR}$ & AVE \\
\hline Product Attribute & & 0.979 & 0.982 & 0.889 \\
\hline PA1 & 0.947 & & & \\
\hline PA2 & 0.873 & & & \\
\hline PA3 & 0.940 & & & \\
\hline PA4 & 0.954 & & & \\
\hline PA5 & 0.951 & & & \\
\hline PA6 & 0.962 & & & \\
\hline PA7 & 0.968 & & & \\
\hline Price & & 0.727 & 0.829 & 0.552 \\
\hline PR1 & 0.821 & & & \\
\hline PR2 & 0.830 & & & \\
\hline PR3 & 0.606 & & & \\
\hline PR 4 & 0.692 & & & \\
\hline Customer Satisfaction & & 0.993 & 0.995 & 0.979 \\
\hline CS1 & 0.982 & & & \\
\hline CS2 & 0.994 & & & \\
\hline CS3 & 0.993 & & & \\
\hline CS4 & 0.988 & & & \\
\hline Purchase Intention & & 0.945 & 0.958 & 0.819 \\
\hline PI1 & 0.873 & & & \\
\hline PI2 & 0.905 & & & \\
\hline PI3 & 0.931 & & & \\
\hline PI4 & 0.887 & & & \\
\hline PI5 & 0.926 & & & \\
\hline
\end{tabular}

In the validity test presented in table 2, it is known that the value of each loading factor on each indicator of exogenous and endogenous variables has a value above 0.7, and likewise, for the acquisition of the AVE value, the value is above 0.5. Furthermore, the value for each of the above reliability, for each endogenous variable, namely, product attributes, price, and customer satisfaction, obtained a composite reliability value above 0.7 and for exogenous variables, namely, purchase interest also got a composite reliability value above 0,7 . Then the Cronbach's alpha for all endogenous and exogenous variables obtained a deal above 0.7 , proving that all research variables have good reliability numbers. 


\section{Inner Model Measurement}

Inner model measurement is done by bootstrapping research data using SmartPLS 3.2.9. There are two results obtained from bootstrapping; the first is the significance of the two related variables and the study's R-square. The Rsquare value is a value that shows the ability of exogenous variables to build endogenous variables. According to (Chin et al., 2008), there are three categories of R-square values if the R-square value is 0.19 , the relationship between exogenous variables forming endogenous variables is weak, if it is 0.33 , it means the connection is moderate, and if the value is 0.67 it indicates that the relationship is strong. While (Sarwono, 2016) states that if the R-square value is more than 0.67 , the relationship between endogenous and exogenous is powerful.

By the R-square value for the customer satisfaction variable, this study found an $R^{2}$ of 0.212 and purchase intention is 0.238 , which importance lies in the value range below 0.33 , so it can be concluded that all exogenous variables in explaining endogenous are weak. Furthermore, to prove the hypothesis testing, a significance test is used to determine the relationship between exogenous variables and endogenous variables. The criterion for significance is seen from the p-value. With a significance level of $5 \%$, if the p-value between exogenous and endogenous variables is less than 0.05 , the exogenous variable significantly affects endogenous variables; on the contrary, if the value is more significant than 0,5 .

Table 3. Path Coefficients Test Results

\begin{tabular}{|c|c|c|c|c|}
\hline Path Between Variables & Coeff. & t-value & p-value & Conclusion \\
\hline $\begin{array}{l}\text { Product Attribute >> } \\
\text { Customer Satisfaction }\end{array}$ & 0.177 & 2,911 & 0.004 & H1 Accepted \\
\hline Price $>>$ Customer Satisfaction & 0.345 & 5,469 & 0.000 & H2 Accepted \\
\hline $\begin{array}{c}\text { Product Attribute }>>\text { Purchase } \\
\text { Intention }\end{array}$ & 0.140 & 2,077 & 0.038 & H3 Accepted \\
\hline Price $>>$ Purchase Intention & 0.299 & 4,558 & 0.000 & H4 Accepted \\
\hline $\begin{array}{c}\text { Customer Satisfaction }>> \\
\text { Purchase Intention }\end{array}$ & 0.165 & 2,347 & 0.019 & H5 Accepted \\
\hline $\begin{array}{l}\text { Product Attribute }>>\text { purchase } \\
\text { intention mediated by } \\
\text { customer satisfaction }\end{array}$ & 0.029 & 1,674 & 0.095 & H6 Denied \\
\hline $\begin{array}{c}\text { Price >> purchase intention } \\
\text { mediated by customer } \\
\text { satisfaction }\end{array}$ & 0.057 & 2,138 & 0.033 & H7 Accepted \\
\hline
\end{tabular}


Based on the processed data presented in table 3, the significance test of the direct relationship between exogenous and endogenous variables can be said that overall exogenous variables significantly affect endogenous variables. Thus, all hypothesis development in research can be well accepted. Furthermore, to obtain conclusions regarding the effect of mediation, an indirect effect test was conducted between endogenous and exogenous variables mediated by consumer satisfaction. From the indirect impact results, it is concluded that consumer satisfaction cannot mediate the relationship between product attributes and purchase intention. In contrast, the relationship between price and purchase intention shows that consumer satisfaction can meditate.

\section{DISCUSSION}

Product attributes have a positive and significant effect on customer satisfaction. Product attributes can provide a clear picture of the quality of a product. It is necessary to have a deep understanding of consumers to compare expectations with desired expectations (Qomariah, 2018). Studies (Kang et al., 2014) states that the product attribute is a development that involves determining the benefits to be provided. In theory, it can be proven that product attributes can give gifts to customers and customer satisfaction. The results of this study are in line with the research results (Y. Wang et al., 2018), with the customer behavior theory approach, which states that there is a significant effect of product attributes on washing machine products on the level of customer satisfaction. The same thing was conveyed from the research results (Toufani et al., 2017), which shows that product attributes, such as color, design, overall appearance, texture/touch, beauty, shape, have a significant effect on the satisfaction of purchasing smartphone products. The results of this research are also supported by the results of the study (Choudhury \& Gulati, 2020), with the orientation of the Kano model, which finds four types of attributes such as water resistance, wireless charging, fingerprint sensor, sound control facilities are included in the category affecting consumer satisfaction.

Price has a positive and significant effect on customer satisfaction based on the coefficient path test results in Table 3. According to (Han et al., 2015), there is a possibility that the price suitability can support customer satisfaction after achieving the level of profit that the customer wants. In general, customers want to use the price as a marker of happiness because the customer wants to review the price of a product being offered before carrying out the activity to buy (Sudirman, Halim, \& Pinem, 2020). The urgency of the price of a product is oriented towards strategic effectiveness in marketing so that unstable price changes will cause sensitivity to satisfaction (Y.-H. Wang \& Chen, 2016). Various types of smartphone products are offered to the market, providing 
many choices for consumers. Smartphone manufacturers are currently competing to provide mobile phones with advanced features but at relatively low prices (Satriawan \& Setiawan, 2020). This condition drives the level of consumer satisfaction when buying smartphone products with price quotes that match the level of consumer income acceptance. The results of this study are in line with (Pandey et al., 2020) that the impact of varying prices according to the nature of the product affects the level of customer satisfaction. On the other hand, studies explain that the provision of fairness in prices for online transportation services significantly contributes to influencing user satisfaction (Sudirman, et al., 2020). This finding is also supported by other results (Ali Qalati et al., 2019), using the customer behavior theory approach, which shows that customer satisfaction will tend to be better if they receive a price quote relevant to the quality of the product.

The data in Table 3 shows that product attributes have a positive and significant effect on purchase intention. The activity of purchasing a product or service that a customer has tried on a product or service more than once or more in an organized manner is called buying interest (Putri et al., 2020). Purchase interest is a consumer stimulant to repurchase or encourage someone to buy back (Nuraeni, 2014). The characteristics possessed by a product are tested for consistency when a customer is affected by everything that is owned ult wants to generate a willingness to use the product (Kang et al., 2014). Furthermore, the aesthetic elements wrapped in the appearance of a smartphone's product attributes can lead to purchasing intentions by private buyers (Toufani et al., 2017). This result is supported by research from (Popovich \& Hamilton, 2020), which convey precisely the attributes weighted more heavily in the decision to place an item on the intermediate selection list then are given lighter weight in the decision to buy in retail. The same thing was also expressed by (Nation \& Schlegelmilch, 2020), which conveys a linear and rational consumer decision-making process by focusing on product attributes with the slogan emphasizing environmental aspects of sustainability. Further research (Lee et al., 2017) focuses on purchase interest in online stores, highlighting that the product attribute factors have positive and significant benefits on customer purchases.

Price has a positive and significant effect on purchase intention based on the path coefficient test results. The price factor is crucial to influence and attract consumers' considerations and choices to buy products (Bhatti, 2018). The review of the customers stands as the product evaluation. As a result, it implies a strong purchase desire, and possibly carrying out purchasing activities will also be greater (Wong, 2019). Furthermore, with the correspondence between perceived price and the benefits received, namely the manifestation of satisfaction with something received, the result creates an interest in repurchasing the product. The results of this study are in line with previous research that the price factor on smartphone products has a significant impact on consumer purchasing decisions (Sudirman, Halim, Pakpahan, et al., 
2020). This finding is also supported by research results (Japarianto \& Adelia, 2020) that the price offered on the E-Commerce platform has a significant influence on consumer purchase interest. Apart from the two previous studies, finding from (Santoso, 2018) also corroborates the results of this study, with the results of research concluding that the reflection of consumer buying interest in automatic products is more or less influenced by the price offer given.

The path coefficient test data in Table 3 also shows that satisfaction has a positive and significant effect on purchase intention. To win customers' hearts, a marketer needs to develop an understanding of how consumers intend to make a purchase (Adji \& Semuel, 2014). The intention of the consumer's role in purchasing is strongly influenced by the personal interests that arise and the perceived satisfaction. The implication of satisfaction with a product tends to influence consumer behavior to make repurchases (Japarianto \& Adelia, 2020). This condition of customer satisfaction arises from the product he uses. The higher the consumer's interest in making further purchases (Sari \& Lestari 2019). The results of this research are in line with studies (Hossain \& Zhou, 2018), which conveyed the acceptance of optimal customer satisfaction in the use of mobile payments made a significant contribution to buying interest. The same thing was represented by (Goh et al., 2016), the acceptance of satisfaction by consumers influence that repeated buying interest in smartphone products. Findings from (Adji \& Semuel, 2014; Neldi et al., 2020) also confirm the results of previous studies using the satisfaction variable as a predictor of consumer buying interest, and the results have a significant effect.

The indirect effect data analysis results show that consumer satisfaction cannot mediate the relationship between product attributes and purchase intention. Most smartphone users are employees and civil servants who prioritize the product attributes attached to the smartphone itself. Various types of smartphone products are offered to the market, providing many choices for consumers. Smartphone manufacturers are currently competing to provide mobile phones with advanced features but at relatively low prices (Satriawan \& Setiawan, 2020). This condition triggers consumers to consider making purchases at certain smartphone brands because there are other factors rather than paying attention to aspects of the product attributes offered. The results of this study are in line with (Kusmayasari, 2014), which states that consumer satisfaction cannot provide a mediating effect between the relationship between product attributes and purchase intention. On the other hand, the results of this study are inconsistent (Goh et al., 2016) through the customer behavior theory approach, which concludes that satisfaction partially mediates the relationship between product attributes and purchase intention. The manufacturers can emphasize product attributes to shorten the effort required for consumers to familiarize themselves with the new smartphone.

The indirect effect data analysis results show that consumer satisfaction can mediate the relationship between price and purchase intention. Higher 
price expectations have implications for the decision-making process. The amount and complexity of price expectations depend primarily on customer interest, especially on price transparency, price-quality ratios, and relative prices, and of course, these dimensions affect satisfaction (Rama, 2020). On average, respondents who have a middle income tend to be interested in buying smartphone products because the price and level of satisfaction received are in a balanced proportion. Besides, physiological techniques and communication initiatives may also help sustain consumers through the interaction and emotional connection between consumers and product prices (Goh et al., 2016). Research conducted (Ali Qalati et al., 2019) also confirms the existence of a mediating relationship between consumer purchasing behavior between price and customer satisfaction. Other findings that are consistent with this study were also presented (Ghassani \& Suryoko, 2017); (Palma \& Andjarwati, 2016) and (Resti, Devi; Soesanto, 2016), which states that consumer satisfaction can provide a mediating effect between the relationship between price and purchase intention.

\section{FURTHER STUDY}

The conduct and results of this research have several limitations, along with their substantial contribution to literature review and practice. This research only uses product attribute variables and price as predictors of satisfaction and purchase interest. For further investigation, it is expected to develop and explore customer buying interest with different model theories and concepts to gain a broader understanding. Second, the majority of respondents live in Pematangsiantar City and its surroundings. Future research is expected to reach a more comprehensive geographic range of respondents to generalize findings. Therefore, further research is expected to provide better contributions practically.

\section{REFERENCES}

Adji, J., \& Semuel, D. H. (2014). Pengaruh Satisfaction Dan Trust Terhadap Minat Beli Konsumen (Purchase Intention) Di Starbucks the Square Surabaya. Jurnal Manajemen Pemasaran Petra, 2(1), 1-10.

Ahmad, A., \& Barukab, O. (2020). A Novel Approach to Identify the Categories of Attributes for the Three-Factor Structure in Customer Satisfaction. Complexity, 2020(1). https:// doi.org/10.1155/2020/9506941

Ali, F. (2016). Hotel website quality, perceived flow, customer satisfaction and purchase intention. Journal of Hospitality and Tourism Technology, 7(2), 213228. https:/ / doi.org/10.1108/JHTT-02-2016-0010

Ali Qalati, S., Li, W., Iqbal, S., Yassir Hussain, R., \& Ali, S. (2019). Impact Of Price On Customer Satisfaction; Mediating Role Of Consumer Buying 
Behaviour In Telecom Secto. International Journal of Research, 06(04), 150165.

Ann, B. Y., Chen, C. M., \& Liu, H. M. (2018). Product Attributes and Purchase Intention for Smartphones: A Moderated Mediation Model. International Journal of Mobile Communications, 16(1), 1. https:// doi.org/10.1504/ijmc.2018.10005322

Bangsa, A. B., \& Schlegelmilch, B. B. (2020). Linking sustainable product attributes and consumer decision-making: Insights from a systematic review. Journal of Cleaner Production, 245. https:// doi.org/10.1016/j.jclepro.2019.118902

Bhatti, A. (2018). Sales Promotion and Price Discount Effect on Consumer Purchase Intention with the Moderating Role of Social Media in Pakistan. International Journal of Business Management, 3(4), 50-58.

Bringula, R. P., Moraga, S. D., Catacutan, A. E., Jamis, M. N., \& Mangao, D. F. (2018). Factors influencing online purchase intention of smartphones: A hierarchical regression analysis. Cogent Business and Management, 5(1), 1-18. https:/ / doi.org/10.1080/23311975.2018.1496612

Chang, J. (2011). Conceptualising the value of web content in marketing research. Marketing Intelligence and Planning, 29(7), 687-696. https:/ / doi.org/10.1108/02634501111178703

Chen, L. Y. (2013). Antecedents of customer satisfaction and purchase intention with mobile shopping system use. International Journal of Services and Operations Management, 15(3), 259-274. https:// doi.org/10.1504/IJSOM.2013.054442

Cheong, H. J., \& Morrison, M. A. (2008). Consumers' Reliance on Product Information and Recommendations Found in UGC. Journal of Interactive Advertising, 8(2), 38-49. https:// doi.org/10.1080/15252019.2008.10722141

Chi, T. (2018). Mobile Commerce Website Success: Antecedents of Consumer Satisfaction and Purchase Intention. Journal of Internet Commerce, 17(3), 189215. https:/ / doi.org/10.1080/15332861.2018.1451970

Chin, W. W., Peterson, R. A., \& Brown, S. P. (2008). Structural Equation Modeling In Marketing: Some Practical Reminders Structural Equation Modeling In Marketing: Some Practical Reminders. Journal of Marketing Theory and Practice ISSN:, 16(4), 287-298. https:// doi.org/10.2753/MTP1069-6679160402

Cho, M., Bonn, M. A., Moon, S., \& Chang, H. (Sean). (2020). Home chef meal kits: Product attributes, perceived value and repurchasing intentions the moderating effects of household configuration. Journal of Hospitality and Tourism Management, 45(March), 192-202. https:// doi.org/10.1016/j.jhtm.2020.08.011

Choudhury, D. K., \& Gulati, U. (2020). Product attributes based on customer's perception and their effect on customer satisfaction: the Kano analysis of mobile brands. Decision, 47(1), 49-60. https:// doi.org/10.1007/s40622-020- 
00233-x

Dash, G., Kiefer, K., \& Paul, J. (2021). Marketing-to-Millennials: Marketing 4.0, customer satisfaction and purchase intention. Journal of Business Research, 122(October 2020), 608-620. https:// doi.org/10.1016/j.jbusres.2020.10.016

Evanita, S., \& Trinanda, O. (2017). Pengaruh Atribut Produk Terhadap Minat Beli Makanan Ringan Tradisional Economac. Economac Volume, 1(2), 6-11. https:/ / doi.org/10.24036/20171237

Ghassani, M., \& Suryoko, S. (2017). Pengaruh Kualitas Produk Dan Harga Terhadap Minat Beli Ulang Bandeng Juwana Vaccum Melalui Kepuasan Konsumen Sebagai Variabel Intervening (Studi Kasus Pada Pelanggan Pt. Bandeng Juwana Elrina Semarang). Jurnal Ilmu Administrasi Bisnis, 6(4), 311-319.

Ghozali, I. (2014). Structural Equation Modeling, Metode Alternatif dengan Partial Least Square (PLS). Badan Penerbit Universitas Diponegoro.

Goh, S. K., Jiang, N., Hak, M. F. A., \& Tee, P. L. (2016). Determinants Of Smartphone Repeat Purchase Intention Among Malaysians: A Moderation Role Of Social Influence And A Mediating Effect Of Consumer Satisfaction. International Review of Management and Marketing, 6(4), 993-1004.

Hair, J. F. (2014). Multivariat Data Analysis 7th Edition. Pearson Prentice Hall.

Han, S. H., Nguyen, B., \& Lee, T. J. (2015). Consumer-Based Chain Restaurant Brand Equity, Brand Reputation, And Brand Trust. International Journal of Hospitality Management, 50(1), 84-93. https:/ / doi.org/10.1016/j.ijhm.2015.06.010

Handoko, B. (2017). Pengaruh Promosi, Harga Dan Kualitas Pelayanan Terhadap Kepuasan Konsumen Pada Titipan Kilat JNE Medan. Jurnal Ilmiah Manajemen Dan Bisnis, 18(1), 61-72. https:// doi.org/10.30596/jimb.v18i1.1098

Hasan, A. (2013). Marketing dan Kasus-Kasus Pilihan (Edisi 1). CAPS (Center For Academic Publishing Service).

Herrmann, A., Xia, L., Kent, M. B., \& Huber, F. (2007). The influence of price fairness on customer satisfaction: An empirical test in the context of automobile purchases. Journal of Product and Brand Management, 16(1), 4958. https://doi.org/10.1108/10610420710731151

Hoffmann, N. C., Symmank, C., Mai, R., Stok, F. M., Rohm, H., \& Hoffmann, S. (2020). The influence of extrinsic product attributes on consumers' food decisions: review and network analysis of the marketing literature. Journal of Marketing Management, 36(9-10), 888-915. https:// doi.org/10.1080/0267257X.2020.1773514

Hossain, M. S., \& Zhou, X. (2018). Impact of m-payments on purchase intention and customer satisfaction: perceived flow as mediator. International Journal of Science and Business, 2(3), 503-517. https:// doi.org/10.5281/zenodo.1408692

Hsiao, C. H., Chang, J. J., \& Tang, K. Y. (2016). Exploring The Influential Factors In Continuance Usage Of Mobile Social Apps: Satisfaction, Habit, And 
Customer Value Perspectives. Telematics and Informatics, 33(2), 342-355. https:// doi.org/10.1016/j.tele.2015.08.014

Hsu, C. L., Chang, C. Y., \& Yansritakul, C. (2017). Exploring purchase intention of green skincare products using the theory of planned behavior: Testing the moderating effects of country of origin and price sensitivity. Journal of Retailing and Consumer Services, 34(October 2016), 145-152. https:/ / doi.org/10.1016/j.jretconser.2016.10.006

Hsu, C. L., Chang, K. C., \& Chen, M. C. (2012). The impact of website quality on customer satisfaction and purchase intention: Perceived playfulness and perceived flow as mediators. Information Systems and E-Business Management, 10(4), 549-570. https:/ / doi.org/10.1007/s10257-011-0181-5

Ilyas, G. B., Rahmi, S., Tamsah, H., Munir, A. R., \& Putra, A. H. P. K. (2020). Reflective Model Of Brand Awareness On Repurchase Intention And Customer Satisfaction. Journal of Asian Finance, Economics and Business, 7(9), 427-438. https://doi.org/10.13106/JAFEB.2020.VOL7.NO9.427

Imtiaz, M. N., \& Islam, M. K. Ben. (2020). Identifying Significance of Product Features on Customer Satisfaction Recognizing Public Sentiment Polarity: Analysis of Smart Phone Industry Using Machine-Learning Approaches. Applied Artificial Intelligence, 00(00), 1-17. https:/ / doi.org/10.1080/08839514.2020.1787676

Japarianto, E., \& Adelia, S. (2020). Pengaruh Tampilan Web Dan Harga Terhadap Minat Beli Dengan Kepercayaan Sebagai Intervening Variable Pada E-Commerce Shopee. Jurnal Manajemen Pemasaran, 14(1), 35-43. https:// doi.org/10.9744/pemasaran.14.1.35-43

Kang, S., Hur, W. M., \& Son, M. (2014). The moderating role of sociodemographics on smartphone adoption. International Journal of Mobile Communications, 12(5), 532-550. https:/ / doi.org/10.1504/IJMC.2014.064597

Katt, F., \& Meixner, O. (2020). Is it all about the price? An analysis of the purchase intention for organic food in a discount setting by means of structural equation modeling. Foods, 9(4), 1-13. https:// doi.org/10.3390/foods9040458

Kaushal, S. K., \& Kumar, R. (2016). Factors Affecting the Purchase Intention of Smartphone: a Study of Young Consumers in the City of Lucknow. Pacific Business Review International, 8(12), 1-16.

Khaleeli, M., Oswal, N., \& Sleem, H. (2021). The moderating effect of price consciousness on the relationship between green products purchase intention and customers' purchase behavior: Does environmental knowledge matters? ,. Management Science Letters, 11, 1651-1658. https:/ / doi.org/10.5267/j.msl.2020.12.007

Kotler, P., \& Armstrong, G. (2008). Prinsip-Prinsip Pemasaran (Edisi 12). Erlangga.

Kurniawati, T., Irawan, B., \& Prasodjo, A. (2019). Analisis Pengaruh Kualitas Pelayanan, Harga, dan Brand Image Terhadap Kepuasan Konsumen 
Restoran Pizza Hut Cabang Jember. E-Journal Ekonomi Bisnis Dan Akuntansi, 6(2), 147. https:/ / doi.org/10.19184/ejeba.v6i2.11159

Kusmayasari, K. (2014). PENGARUH ATRIBUT PRODUK TERHADAP KEPUTUSAN PEMBELIAN DAN KEPUASAN KONSUMEN GREEN PRODUCT (Survei pada Konsumen Sariayu Martha Tilaar yang Tergabung dalam Followers Official Account Twitter @Sariayu_MT). Jurnal Administrasi Bisnis S1 Universitas Brawijaya, 14(1), 84238.

Lee, W. I., Cheng, S. Y., \& Shih, Y. T. (2017). Effects among product attributes, involvement, word-of-mouth, and purchase intention in online shopping. Asia Pacific Management Review, 22(4), 223-229. https:// doi.org/10.1016/j.apmrv.2017.07.007

Lie, D., Sudirman, A., Efendi, E., \& Butarbutar, M. (2019). Analysis of Mediation Effect Of Consumer Satisfaction On The Effect Of Service Quality, Price and Consumer Trust On Consumer Loyalty. INTERNATIONAL JOURNAL OF SCIENTIFIC \& TECHNOLOGY RESEARCH, 8(8), 421-428.

Lin, F. H., Tsai, S. B., Lee, Y. C., Hsiao, C. F., Zhou, J., Wang, J., \& Shang, Z. (2017). Empirical Research on Kano's model and Customer Satisfaction. PLoS ONE, 12(9), 1-22. https:/ / doi.org/10.1371/journal.pone.0183888

Madahi, A., \& Sukati, I. (2012). The Effect of External Factors on Purchase Intention amongst Young Generation in Malaysia. International Business Research, 5(8). https:/ / doi.org/10.5539/ibr.v5n8p153

Martins, J., Costa, C., Oliveira, T., Gonçalves, R., \& Branco, F. (2019). How Smartphone Advertising Influences Consumers' Purchase Intention. Journal of Business Research, 94, 378-387. https:// doi.org/10.1016/j.jbusres.2017.12.047

Masud, A., Haque, A., \& Azam, F. (2011). Factors influencing customer loyalty towards fast food restaurants. International Tourism and Hospitality Journal, 10(3), 12-16.

Murtingsih, T., Mohammad, S. R., \& Retnaningsih, W. (2019). Titi INFLUENCES OF BRAND EXPERIENCE, BRAND TRUST, AND BRAND LOVE TOWARD PURCHASE INTENTION BY WORD OF MOUTH AND BRAND LOYALTY AS INTERVENING VARIABLES IN FASHION BRANDED IN EAST SURABAYA. Archives of Business Research, 7(9), 106120. https:/ / doi.org/10.14738/abr.79.6833

Neldi, M., Kumbara, V. B., \& Yunita, Y. (2020). Mengukur Minat Beli Konsumen Melalui Kepuasan Konsumen Pada PT. Menara Agung Padang. Jurnal Ilmu Manajemen Terapan, 2(1), 111-127. https:// doi.org/10.31933/jimt.v2i1.328

Nugroho, N. A., Suharyono, \& Sunarti. (2015). Pengaruh Atribut Produk Terhadap Kepuasan Pelanggan Dan Loyalitas Pelanggan. Jurnal Administrasi Bisnis, 20(1), 1-8.

Nuraeni, B. S. (2014). Analisis Faktor-Faktor Yang Mempengaruhi Minat Kunjung Ulang Wisatawan Museum Ranggawarsita Semarang. Jurnal Bisnis Strategi, 23(1), 1-20.

Oktarini, R. (2019). Pengaruh Kualitas Pelayanan Dan Harga Terhadap 
Kepuasan Pelanggan Pengguna Jasa Aplikasi Gojek Di Kota Tangerang. Jurnal Sekretari Universitas Pamulang, 6(2), 10. https:/ / doi.org/10.32493/skr.v6i2.3305

Palma, M. A., \& Andjarwati, A. L. (2016). Pengaruh Kualitas Produk, Kemudahan, Dan Harga Terhadap Niat Beli Ulang Dengan Kepuasan Sebagai Variabel Intervening (Studi Pada Pelanggan Produk Fashion Melalui Toko Online Di Surabaya). Jurnal Riset Ekonomi Dan Manajemen, 16(1), 84. https://doi.org/10.17970/jrem.16.60106.id

Pandey, N., Tripathi, A., Jain, D., \& Roy, S. (2020). Does Price Tolerance Depend Upon The Type Of Product In E-Retailing? Role Of Customer Satisfaction, Trust, Loyalty, And Perceived Value. Journal of Strategic Marketing, 28(6), 522-541. https://doi.org/10.1080/0965254X.2019.1569109

Popovich, D., \& Hamilton, R. (2020). Intermediate Choice Lists: How Product Attributes Influence Purchase Likelihood in a Self-Imposed Delay. Journal of Retailing, 1(1). https:/ / doi.org/10.1016/j.jretai.2020.07.002

Putra, Y. D., Deviana, R., Talalahi, W., \& Yumte, A. (2020). Pengaruh Kualitas Tampilan Website Dan Kepuasan Pelanggan Terhadap Minat Beli ( Studi Kasus Pada Traveloka ). Jurnal Eksekutif, 17(1), 69-83.

Putri, D. E., Sinaga, O. S., Agustina, S. S., Silitonga, H. P., \& Sudirman, A. (2020). Minat Kunjungan Ulang Pasien yang Ditinjau dari Aspek Persepsi dan Kepercayaan pada Klinik Vita Medistra Pematangsiantar. Inovbiz: Jurnal Inovasi Bisnis 8, 8(1), 41-46.

Qomariah, N. (2018). Impact of Customer Value, Brand Image and Product Attributes to Satisfaction and Loyalty Tourism Visitors in Jember Regency. Mediterranean Journal of Social Sciences, 8(5-1), 129-135. https:/ / doi.org/10.2478/mjss-2018-0105

Rama, A. (2020). Strategic Pricing By Islamic Banks And The Impact On Customer Satisfaction And Behavioral Intention. Journal of Islamic Accounting and Business Research, 11(9), 2017-2033. https:/ / doi.org/10.1108/JIABR-04-2019-0078

Ramaseshan, B., \& Stein, A. (2014). Connecting The Dots Between Brand Experience And Brand Loyalty: The Mediating Role Of Brand Personality And Brand Relationships. Journal of Brand Management, 21(7), 664-683. https:// doi.org/10.1057/bm.2014.23

Resti, Devi; Soesanto, H. (2016). Pengaruh Persepsi Harga, Kualitas Pelayanan melalui Kepuasan Pelanggan terhadap Minat Beli Ulang pada Rumah Kecantikan Sifra Di Pati. Diponegoro Journal of Management, 5(1), 1-12.

Santoso, P. H. (2018). Pengaruh Harga, Citra Merek, Dan Kredibilitas Perusahaan Terhadap Niat Membeli Konsumen Pada Produk Kawasaki Di Kota Yogyakarta. Journal of Economic, Business and Accounting, 1(2), 209-220. Sari, M. R., \& Lestari, R. (2019). Pengaruh Persepsi Harga, Kualitas Pelayanan Dan Kualitas Produk Terhadap Kepuasan Dan Dampaknya Pada Minat Pembelian Ulang Konsumen Keretaapi Kelas Eksekutif Argo Parahyangan. 
Jurnal Ilmu Manajemen, $\quad$ 15(1), 30-44. https:// doi.org/10.9744/pemasaran.7.1.25-32

Sarwono, J. (2016). Membuat Skripsi, Tesis dan Disertasi dengan Partial Least Square SEM (PLS - SEM). Andi Offset.

Satria, A. A. (2017). Pengaruh Harga, Promosi, Dan Kualitas Produk Terhadap Minat Beli Konsumen Pada Perusahaan A-36. PERFORMA: Jurnal Manajemen Dan Start-Up Bisnis, 2(1), 45-53. https:// doi.org/10.34127/jrlab.v6i1.169

Satriawan, K. A., \& Setiawan, P. Y. (2020). The Role Of Purchase Intention In Mediating The Effect Of Perceived Price And Perceived Quality On Purchase Decision. International Research Journal of Management, IT and Social Sciences, 7(3), 38-49. https:// doi.org/10.21744/irjmis.v7n3.887

Soujanya, K., \& Daniel, P. (2020). Impact Of Product Attributes On Retail Customer Satisfaction. European Journal of Molecular and Clinical Medicine, 7(8), 2340-2346.

Sudirman, A., Efendi, E., \& Harini, S. (2020). Kontribusi harga dan kepercayaan konsumen untuk membentuk kepuasan pengguna transportasi berbasis aplikasi. Journal of Business and Banking, 9(2), 323-335. https:/ / doi.org/10.14414/jbb.v9i2.2078

Sudirman, A., Halim, F., Pakpahan, G. E., \& Sherly. (2020a). Faktor-Faktor Yang Mendorong Minat Beli Smartphone Merek OPPO Dalam Kondisi Pandemi Covid-19. Seminar Nasional Manajemen, Ekonomi Dan Akuntansi, September, 1-11.

Sudirman, A., Halim, F., Pakpahan, G. E., \& Sherly. (2020b). Faktor-Faktor Yang Mendorong Minat Beli Smartphone Merek OPPO Dalam Kondisi Pandemi Covid 19. Seminar Nasional Manajemen, Ekonomi Dan Akuntansi, September, $1-11$.

Sudirman, A., Halim, F., \& Pinem, R. J. (2020). Kepercayaan Sebagai Pemediasi Dampak Citra Merek dan Harga Terhadap Kepuasan Konsumen Gojek. Jurnal Pemasaran Kompetitif, 3(3), 66-76.

Sudirman, A., Sherly, Butarbutar, M., Nababan, S. T., \& Puspitasari, D. (2020). Loyalitas Pelanggan Pengguna Gojek Ditinjau Dari Aspek Kualitas Pelayanan dan Kepuasan Konsumen. Procuration: Jurnal Ilmiah Manajemen, $8(1), 63-73$.

Suhatman, S., Sari, M. R., Nagara, P., \& Nasfi, N. (2020). Pengaruh Atribut Produk dan Promosi Terhadap Minat Beli Konsumen Kota Pariaman di Toko Online Shopee. Jurnal Bisnis, Manajemen, Dan Ekonomi, 1(2), 26-41. https://doi.org/10.47747/jbme.v1i2.81

Toufani, S., Stanton, J. P., \& Chikweche, T. (2017). The Importance Of Aesthetics On Customers' Intentions To Purchase Smartphones. Marketing Intelligence E Planning, 35(3), 316-338.

Wang, Y.-H., \& Chen, L.-Y. (2016). An Empirical Study of the Effect of Perceived Price on Purchase Intention Evidence from Low-Cost Carriers. International Journal of Business and Social Science, 7(4), 97-107. 
Wang, Y., Lu, X., \& Tan, Y. (2018). Impact Of Product Attributes On Customer Satisfaction: An Analysis Of Online Reviews For Washing Machines. Electronic Commerce Research and Applications, 29, 1-11. https:// doi.org/10.1016/j.elerap.2018.03.003

Wantara, P., \& Tambrin, M. (2019). The Effect of Price and Product Quality Towards Customer Satisfaction and Customer Loyalty on Madura Batik. International Tourism and Hospitality Journal, 2(1), 1-9.

Wijaya, A., \& Kinder, L. (2020). Pengaruh Price Bundling dan Product Bundling terhadap Niat Membeli yang Dimoderasi oleh Barang Komplementaritas. Jurnal Manajemen, 17(1), 28-38. https:// doi.org/10.25170/jm.v17i1.866

Wilson, N., Keni, K., \& Tan, P. H. P. (2019). The Effect Of Website Design Quality And Service Quality On Repurchase Intention In The E-Commerce Industry: A Cross-Continental Analysis. Gadjah Mada International Journal of Business, 21(2), 187-222. https:/ / doi.org/10.22146/gamaijb.33665

Wong, A. T.-T. (2019). A Study of Purchase Intention on Smartphones of Post 90s in Hong Kong. Asian Social Science, 15(6), 78. https:// doi.org/10.5539/ass.v15n6p78

Zephan, N. (2018). Relationship Between Customer Satisfaction and Customer Loyalty. In CENTRIA UNIVERSITY OF APPLIED SCIENCE Business Management (Issue May).

Zhong, Y., \& Moon, H. C. (2020). What Drives Customer Satisfaction, Loyalty, And Happiness In Fast-Food Restaurants In China? Perceived Price, Service Quality, Food Quality, Physical Environment Quality, And The Moderating Role Of Gender. Foods, 9(4). https:// doi.org/10.3390/foods9040460

Zhou, T. (2011). Examining The Critical Success Factors Of Mobile Website Adoption. Online Information Review, 35(4), 636-652. https:// doi.org/10.1108/14684521111161972 